УДК 902/904

https://doi.org/10.24852/2587-6112.2021.4.80.95

\title{
ПРИМЕНЕНИЕ МЕТОДА ДИСТАНЦИОННОГО ЗОНДИРОВАНИЯ ЗЕМЛИ ДЛЯ ПОИСКА ФОРТИФИЦИРОВАННЫХ ОБЬЕКТОВ НА ТЕРРИТОРИИ МОНГОЛИИ И ЗАПАДНОГО ЗАБАЙКАЛЬЯ ${ }^{1}$
}

\author{
(C) 2021 г. Д.А. Миягашев, Б.А. Базаров, Я.В. Дикий
}

В статье представлены результаты анализа спутниковых снимков из свободных источников территории Монголии и Западного Забайкалья. В ходе мониторинга снимков были выявлены новые объекты, которые интерпретируются нами как остатки древних городищ кочевых Империй - хунну, уйгуров, киданей и Монгольской. В работе дана предварительная датировка и описание объектов.

Ключевые слова: археология хунну, метод дистанционного зондирования земли, уйгуры, кидани, Монгольская империя, древние города, Монголия, Западное Забайкалье.

\section{USE OF EARTH REMOTE SENSING METHOD IN SEARCHING FOR FORTIFIED STRUCTURES IN THE TERRITORY OF MONGOLIA AND WESTERN TRANSBAIKALIA ${ }^{2}$}

\section{A. Miyagashev, B. A. Bazarov, Ya. V. Dikiy}

The paper features the results of an analysis of satellite images of the territory of Mongolia and Western Transbaikalia obtained from free sources. Monitoring of the images allowed to identify new objects, which are interpreted by the authors as the remains of ancient hillforts of nomadic Empires - the Xiongnu, Uighurs, Khitan and Mongol. The paper provides the preliminary dating and description of the objects.

Keywords: archaeology of the Xiongnu, earth remote sensing method, Uighurs, Khitan, Mongol Empire, ancient cities, Mongolia, Western Transbaikal.

Метод дистанционного зондирования земли (ДЗ3) прошел путь от анализа аэрофотоснимков до применения лазерных радаров, установленных на беспилотные летательные аппараты, и успешно применяется в археологии уже более 100 лет. Современные технические средства позволяют успешно использовать Д3З для поиска и изучения археологических объектов как в степной зоне, так и джунглях Амазонки. Источники данного метода включают в себя данные аэро- и космофотосъемки, спутниковых и бортовых сканирующих устройств, спутниковых, бортовых и наземных радаров и т. д. Сложность используемых технических средств обусловлена задачами и целями проводимых исследований. В качестве примера успешной реализации дистанционного зондирования можно упомянуть всемирно известные открытия в Гватемале, Камбодже, Мексике и др., сделанные с применением лазерного радара LIDAR (Evans, 2016; Canuto et al., 2018; Inomata et al., 2020).
Спутниковые снимки высокого разрешения в таких сервисах, как Google, Bing, Esri, Yandex и др., покрывающие большую часть степей Монголии и Западного Забайкалья (рис. 1), позволяют успешно использовать дистанционный метод для поиска и изучения некоторых категорий археологических памятников. Качество изображений позволяет достоверно идентифицировать древние фортифицированные комплексы - города и крепости степных империй Центральной Азии - хунну, уйгуров, киданей, монгольской и маньчжурской.

Истоки градостроительства в монгольских и забайкальских степях относятся ко времени Хуннской державы (209 г. до н. э. - 48 г. н. э.). На настоящий момент известно более 20 поселений и городищ хунну на территории Монголии и Западного Забайкалья (Пэрлээ, 1961; Давыдова, 1985; 1995; Данилов, 2004; Ramseyer etal., 2009; Данилов и др., 2016; Коновалов, 2018; Анхбаяр, 2017; Эрэгзэн, 2017). На территории Монголии городища хунну расположены в гобийском поясе, в Центральной и

Работа выполнена в рамках государственного задания (проект «Историческое пространство монгольского мира: археологические культуры, общества и государства», № 121031000241-1).

The work was carried out within the framework of a state assignment (project "Historical Space of the Mongol World: Archaeological Cultures, Societies and States”, No. 121031000241-1). 


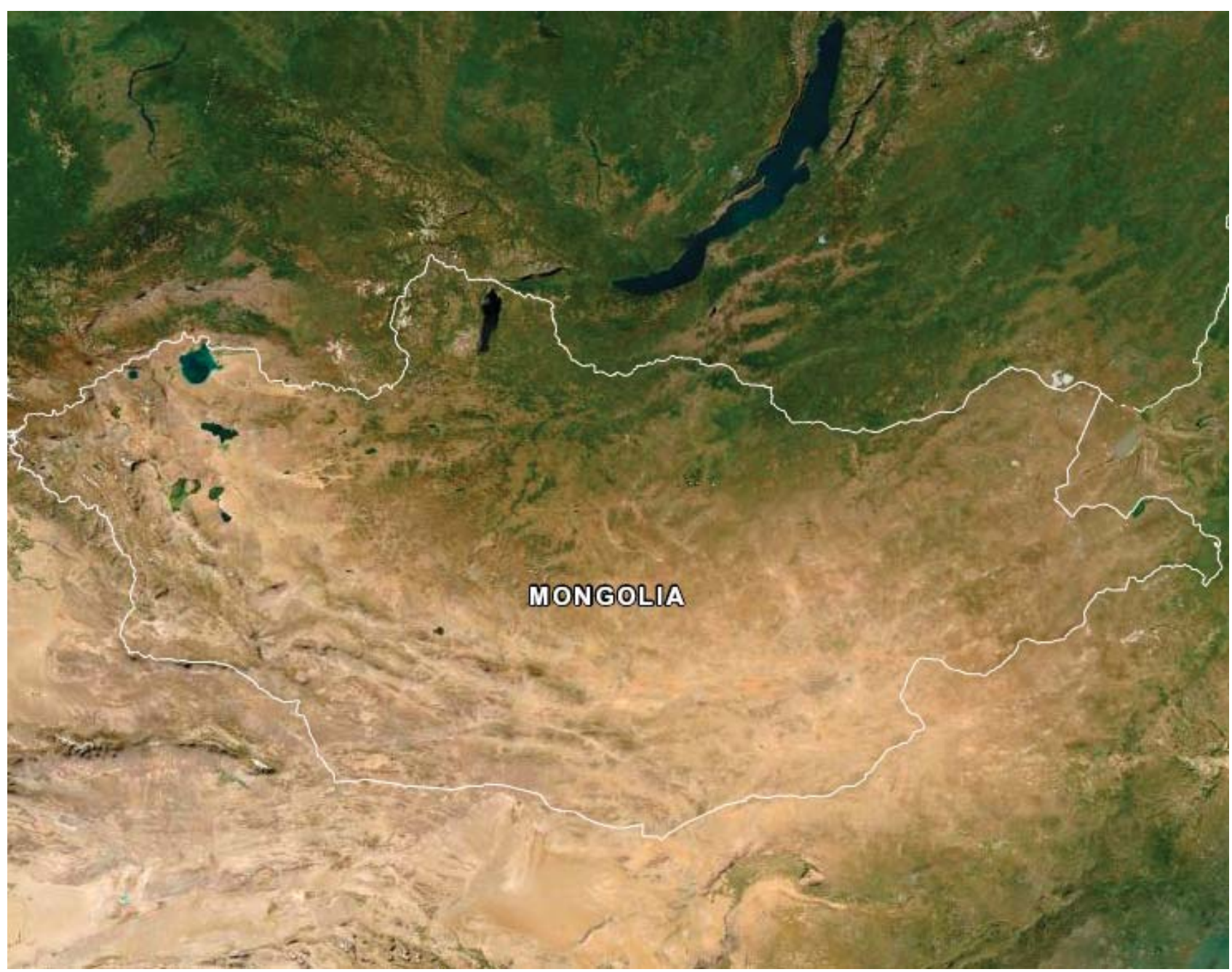

Рис. 1. Спутниковый снимок Монголии и Западного Забайкалья

Fig. 1. Satellite image of Mongolia and Western Transbaikalia

Восточной Монголии в бассейне рек Орхон (Дов дэрс, Талын гурван хэрэм, Бумбатын балгас и др.) и Керулен (Тэрэлжийн дурвулжин, Бурхийн дурвулжин, Хурэт дов, Ундэр дов и др.) (рис. 2). В Западном Забайкалье городища хунну концентрируются в бассейне p. Селенги. По функциональному назначению выделяются административные центры, ритуально-поминальные, пограничные крепости и земледельческо-ремесленные центры (Данилов, 2004; Эрэгзэн, 2017). Для городищ хунну в Монголии характерна квадратная или прямоугольная (близкая к трапеции) форма с земляными платформами в центре. На территории Бурятии известны только два городища хунну и у них более сложная система фортификации - Иволгинское городище было укреплено четырьмя валами и тремя рвами между ними, на городище Баян Ундэр фиксируется большой внешний и внутренний маленький вал (Давыдова, 1995; Данилов, 2004).

Городища уйгурского времени на территории Западного Забайкалья неизвестны, а в
Монголии выявлен ряд памятников, расположенных по долинам Селенги и Орхона Байбалык, Тойтен-Толгой, Тайджин-Чуло, Челим балгас и др. (Данилов, 2004) (рис. 3). Серия городищ для защиты от Кыргызского каганата была построена на территории Тувы (Кызласов, 1969). Для уйгурских городищ характерны прямоугольные формы с оплывшими башнями по углам и в местах расположения ворот. Во внутренней части фиксируются земляные платформы или легко распознаваемые остатки конструкций.

Киданьские городища кроме Монголии известны на территории Внутренней Монголии и в других провинциях Китая (Ивлиев, 1983; Крадин, Ивлиев, 2013). В бассейне рек Тола и Керулен располагались четыре крупных города (Харбухын-балгас, Чинтолгойбалгас, Уланхэрэм, Хэрмэн-дэнж), каменная крепость Эмгэтийн-хэрэм и ряд городков с небольшими валами (Цагаан узурийн хэрэм, Цогтын гэрийн буйр, Найдак уулын дурвэлжин, Дэрсэн хэрэм, Ондгойн дурвэлжин, 


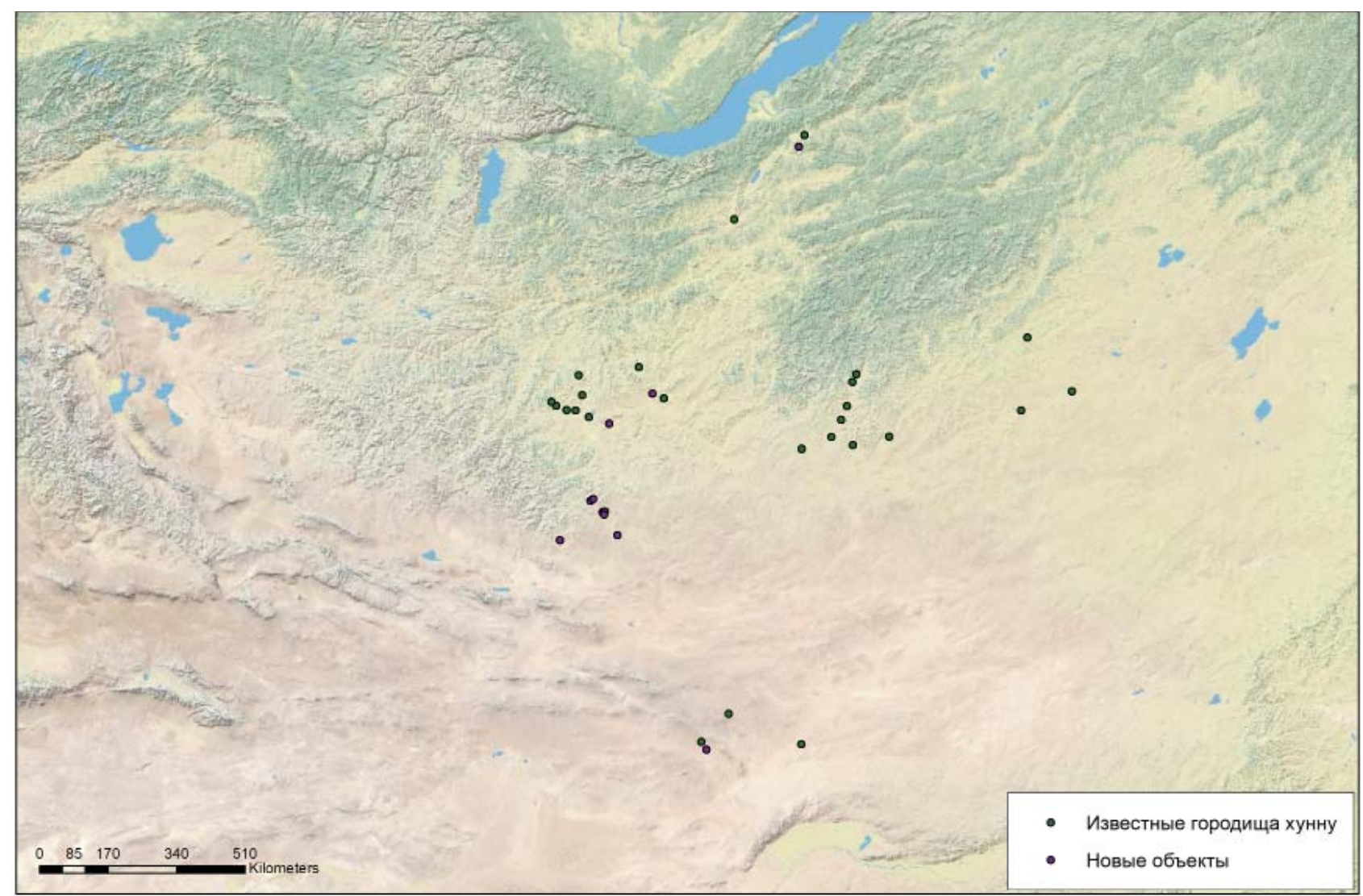

Рис. 2. Карта распространения городищ хунну в Монголии и Западном Забайкалье

Fig. 2. Map of distribution of the Xiongnu hillforts in Mongolia and Western Transbaikalia

Талын хэрэм, Цагаан дэнжийн балгас и др.) (Крадин, Ивлиев, 2011; Очир, Эрдэнэболд, Энхтур, 2015). Серия городищ, выполнявших функцию приграничных форпостов, зафиксирована вдоль северо-восточного «вала Чингис-хана», проходящего по территории восточной Монголии, Российского Забайкалья и северного Китая (Крадин и др., 2019) (рис. 4). Такие города, как Харбухын-балгас, Чинтолгой-балгас, Уланхэрэм, Хэрмэн-дэнж, имели глинобитные валы, построенные по китайской технологии хан-ту, по периметру стен располагались вынесенные вперед угловые и фронтальные башни, внутреннее пространство городов разделялось валами или улицами на прямоугольные кварталы (Данилов, 2004; Крадин и др. 2013; Kradin et al., 2015). Приграничные крепости, расположенные на расстоянии дневного перехода от «вала Чингис-хана», имели квадратные или круглые формы, в некоторых случаях встречается совместное использование - квадратная цитадель, обнесенная кольцевым валом, высота валов достигает высоты 2 м, а ширины 12 м (Крадин и др., 2019).

Для Монгольской империи характерно строительство городов трех типов - имперских столичных мегаполисов (Каракорум, Шанду, Даду), городов - административных центров (Аврага, Хирхира), отдельно стоящих усадебных (Алестуй, Нарсатуй) и дворцовых (Кондуй) комплексов (Киселев, 1961; Древнемонгольские города, 1965; Данилов, 2004; Shiraishi, 2006; Wei Jian, 2008; Hüttel, Erdenebat, 2009; Bemman, Reichert, 2020; Chen Gaohua, 2015; Крадин и др., 2016; Крадин и др., 2019) (рис. 5). Одно из наиболее известных протогородских поселений раннемонгольского времени - Аврага. Оно расположено в излучине Керулена. Для монгольских городов характерно отсутствие мощных укреплений, остатки дворцовых комплексов и усадеб представлены земляными платформами различной высоты и формы. Так столица монгольской империи - Каракорум - имела форму, близкую к прямоугольнику (в южной части - к равнобедренной трапеции). Высота городских стен не превышала 2 м, а глубина рва была не более 1,5 м при ширине до 7 м. Северная стена была длиной 1900 м, восточная - 1320 м, западная - 1520 м, южная прослеживается на 560 м. Город был разделен на несколько участков. В одной зоне располагались усадьбы аристократии и ханский дворец, в другой были расселены чжурчжэньские и китайские ремесленники, третья была занята мусульманскими купцами (Крадин и др., 2016). 


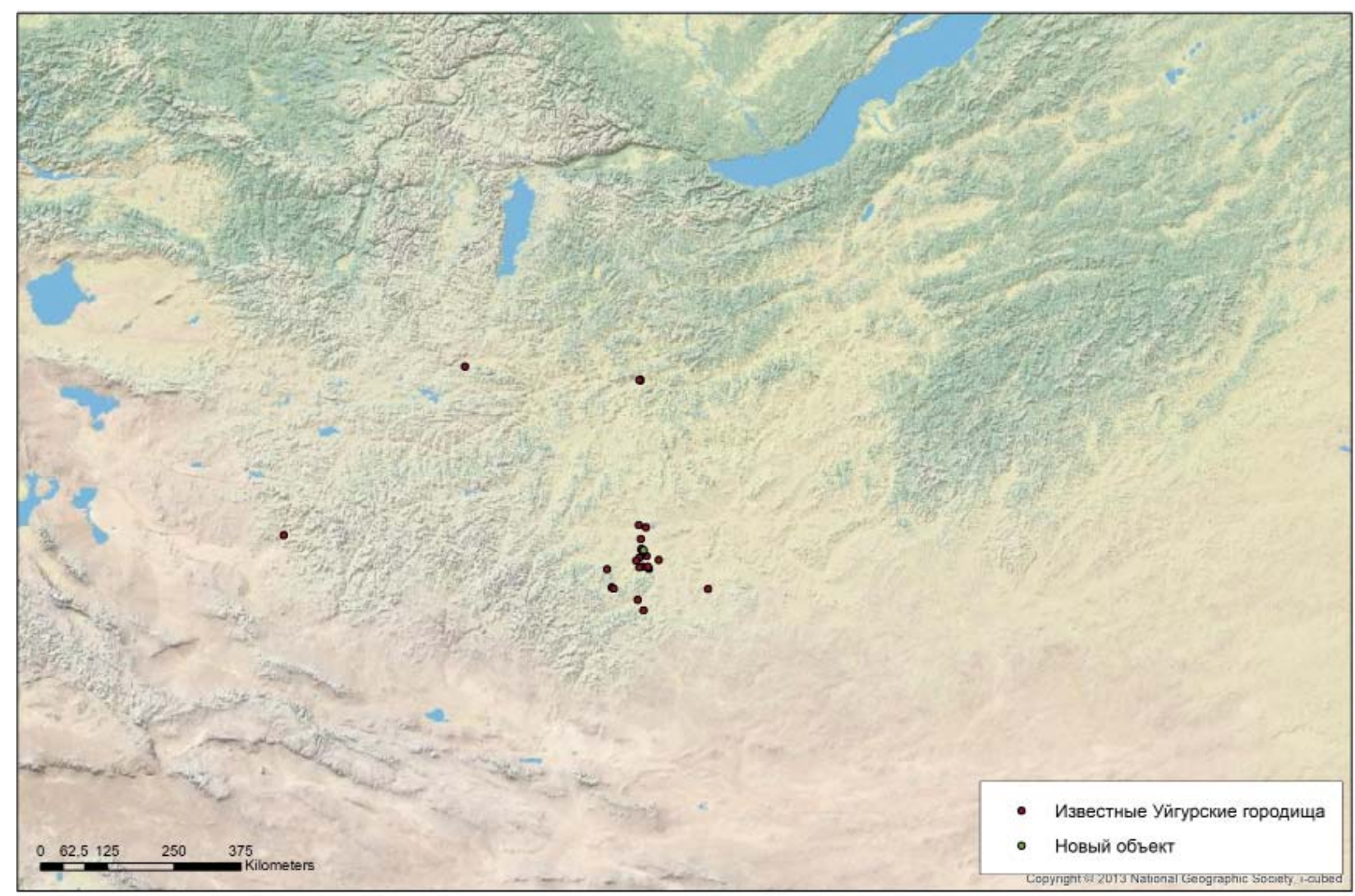

Рис. 3. Карта распространения городищ уйгуров в Монголии

Fig. 3. Map of the distribution of the Uighurs hillforts in Mongolia

В ходе мониторинга спутниковых снимков в сервисе SAS Planet, который дает доступ к базе данных из разных сервисов, на территории Монголии и Западного Забайкалья нами были выявлены объекты с характерными для древних городищ контурами. Сведения об этих объектах не встречаются в опубликованной литературе, вполне вероятно, что некоторые из них известны монгольским коллегам, но еще не были обследованы. В описании указываются приблизительные размеры, снятые по спутниковым снимкам инструментами измерения в картографической программе SAS Planet. Датировка городищ также предварительная и сделана на основании архитектурных особенностей выявленных конструкций и их расположения, во внимание принимались такие факты, как расположение в непосредственной близости схожих памятников и территория распространения городищ в то или иное время.

\section{Городища хунну}

Бага-Бэрх-Уула балгас (рис. 2; 6: 1). Хашаат сомон Архангайского аймака Монголии, в 16,9 км севернее центра сомона в межгорном распадке, в зоне излияния родников на правом берегу р. Хугшин-Орхон, с юга от горы БагаБэрх Уула, ориентировано по сторонам света, имеет трапециевидную форму, длина север- ного вала около 210 м, восточного - 195 м, южного - 207 м, западного - 217, в центре городища фиксируется земляная насыпь. Конструкция валов и планиграфия схожи с городищами хунну.

Омог-Уула-хэрэм (рис. 2; 6: 2). Бурэгхангай сомон Булганского аймака Монголии, на левом берегу р. Хара-Бухын Гол, к востоку от г. Омог Уула. Углы городища ориентированы по сторонам света, трапециевидной формы, длина северо-восточного вала в пределах 180 м, юго-восточного - 145 м, юго-западного 184 м, северо-западного - 131 м. В центре городища земляная насыпь. Конструкция валов и планиграфия схожи с городищами хунну.

Цохетын Булаг I (рис. 2; 6: 3). Тарагт сомон Убурхангайского аймака Монголии, на правом берегу родника Цохетын Булаг, правобережного притока р. Онгийн Гол. Городище ориентировано углами по сторонам света, имеет форму квадрата со сторонами стен 112-115 м. В центре городища со смещением к западному валу располагается земляная насыпь. Конструкция валов и планиграфия схожи с городищами хунну.

Цохетын Булаг II (рис. 2; 6: 4). Тарагт сомон Убурхангайского аймака Монголии, на левом берегу р. Онгийн Гол, в 6 км севернее 
городища Дзун-Баян-Улан I, на приустьевом участке безымянного ручья, выходящего из горного ущелья. Городище ориентировано углами по сторонам света, имеет прямоугольную форму со сторонами стен 92×103 м. Внутри городища, вдоль западного вала, располагаются три земляные платформы. Конструкция валов и планиграфия схожи с городищами хунну.

Арвай-Хэр балгас I (рис. 2; 6: 5). Тарагт сомон Убурхангайского аймака Монголии, на левом берегу р. Онгийн Гол, в 30 км ниже по течению от городищ Дзун-Баян-Улан I и II, на пойменном участке. Городище ориентировано углами по сторонам света, имеет прямоугольную форму со сторонами стен $111 \times 115$ м. Внутри городища, вдоль западного вала, располагаются три земляные платформы. Конструкция валов и планиграфия схожи с городищами хунну.

Арвай-Хэр балгас II (рис. 2; 6: 6). Тарагт сомон Убурхангайского аймака Монголии, в 4,3 км северо-восточнее городища Арвай-Хэр балгас I, на левом берегу р. Онгийн Гол, на надпойменной террасе. Городище ориентировано углами по сторонам света, имеет прямоугольную форму со сторонами стен $211 \times 197$ м. В центре городища располагается земляная платформа. Конструкция валов и планиграфия схожи с городищами хунну.

Арвай-Хэр балгас III (рис. 2; 6: 7). Тарагт сомон Убурхангайского аймака Монголии, на левом берегу р. Онгийн Гол, в 4,9 км ниже по течению от городища Арвай-Хэр балгас II на пойменном участке. Городище ориентировано по сторонам света, южная часть городища разрушена, длина северного вала 60 м, сохранившаяся часть восточного вала имеет длину 60 м, сохранившаяся часть западного вала имеет длину 30 м. Конструкция валов схожа с городищами хунну.

Баян-Гол балгас (рис. 2; 6: 8). Тарагт сомон Убурхангайского аймака Монголии, на правом берегу р. Онгийн Гол, в 42,4 км ниже по течению от городища Арвай-Хэр балгас III на участке надпойменной террасы. Городище ориентировано по сторонам света, имеет квадратную форму со сторонами по 95 м, через городище проходят несколько грунтовых дорог. С юга от основного городища фиксируется малое городище со стенами длиной по 42 м. Вероятно, этот комплекс относится к хуннскому времени.

Гун-Обо балгас (рис. 2; 7: 1). Хайрхандулаан сомон Убурхангайского аймака Монголии, на правом берегу р. Толийн Гол, в пойме реки. Городище ориентировано по сторонам света и имеет в плане форму пятиугольника, три стены, западная, северная и южная, имеют практически одинаковую длину по 186 м, а восточный вал сложен из двух отрезков, образующих посередине небольшой выступающий наружу угол, общая длина восточной стены 199 м. Высота валов, судя по спутниковым снимкам, невысокая, ширина менее 10 м, внутри городища, практически в центре, располагается земляная насыпь. Возможно, городище было сооружено в хуннское время.

Китайская пограничная крепость Бордзонгийн-Булаг (рис. 2; 7: 2). Номгон сомон Умнеговь аймака Монголии, на южном склоне Гобийского Алтая, в урочище БордзонгийнДэд-Тал, в 17 км юго-восточнее городища Баян Булаг (китайский пограничный городок Шоусянчэн). Городище трапециевидной формы, южный вал не читается. Северный вал длиной 53 м, восточный и западный валы длиной по 60 м. Возможно, имеется внешний вал, остатки которого фиксируются с восточной и южной сторон. Синхронен городищам Баян Булаг и Мангасын хурээ.

Ряд объектов, которые могут быть интерпретированы как комплексы с валами хуннского времени, были обнаружены нами в долине p. Тамир на территории сомонов Батцэнгэл и Огийнур Архангайского аймака Монголии. Очевидно, о них идет речь в статье Т. Идэрхангая «Тамирын голын хондий хуннугийн улс төрийн төв болох нь» (Tamir river valley is considered as a political center of Xiongnu) (Идэрхангай, 2012, с. 26) и его докладе «Хүннүгийн хааны зуны ордон Лунчэн буюу луут хот» (Лунчэн - город дракона - летняя резиденция шаньюев Хунну) (Идэрхангай, 2021).

Городище вблизи с. Колобки (рис. 2; 7: 3). Памятник находится в Иволгинском районе Республики Бурятия, на левом берегу р. Селенги, в 1 км юго-западнее с. Колобки. Городище расположено на склоне восточной экспозиции, углами ориентировано по сторонам света, прямоугольной формы, длинной осью вытянуто с юго-запада на северо-восток, северный и восточный валы не фиксируются, в центре, ближе к южному валу, расположена земляная насыпь, ориентировочные размеры 70×80 м. Городище было осмотрено Н.В. Именохоевым в 2019 г.

\section{Уйгурские городища}

Хараат 8 (рис. 3 ; 7: 4). Хотонт сомон Архангайского аймака Монголии, в междуречье рек Джарантай и Орхона, на небольшом острове, 
образованном основным руслом р. Джарантай и его протокой. Этот объект следует включить в группу городищ Хараат (Очир и др., 2019; Ancient settlement of Mongolia, 2020, c. 142-155), расположенных по левому берегу р. Джарантай. Таким образом, с учетом нового городища здесь насчитывается 8 небольших укрепленных комплексов. Городище ориентировано углами по сторонам света и имеет в плане прямоугольную форму со сторонами $80 \times 75$ м, ширина валов более 10 м. Внутри городища фиксируются земляные насыпи и разделения на кварталы.

\section{Киданьские городища}

Четыре круглых городища были выявлены в районе в зоне центрального участка вала Чингисхана. Северо-восточный вал Чингисхана включает в себя 56 городищ, из них 7 круглых городищ. С учетом выявленных больших круглых городищ общее количество их 11 (6,1\%). По своим параметрам к ним близки известные Куладжайское городище, в диаметре достигающее 200 м, Большой круглый Уртуйский городок, диаметр которого 158 м. Следует отметить, что на этих городищах археологический материал не обнаружен. Культурный материал в виде киданьской керамики найден на круглых городищах Харанур-2, Хэрэмтийн-3 и Их-Булак-2, составляющих единый комплекс с прямоугольными городищами и расположенных близко к валу.

Цаган-нур (рис. 4; 8: 1). Чойболсан сомон Дорнод аймака Монголии, в полутора км южнее соленого озера Цаган-Нур, в 22,3 км юго-восточнее вала, в 20,4 км юго-восточнее городища Урд-гэртийн-говь. Конструкция приурочена к левому берегу русла небольшой речки. Валы на всем своем протяжении на снимке демонстрируют хорошую сохранность, без разрывов. Городище круглой формы диаметром 442 м. Ширина вала у основания приблизительно 11 м. Одно из самых крупных городищ. Во внутренней части остатки построек не фиксируются.

Цахилдагын-худук-1 (рис. 4; 8: 2). Гурванзагал сомон Дорнод аймака Монголии, в 12,5 км юго-юго-западнее городища Хэрэмтийн-3, в 10,7 км юго-юго-восточнее вала. Северная часть городища подтапливается водами из источников. Диаметр городища 457 м. Ширина вала у основания приблизительно 10 м. Одно из самых крупных городищ. Во внутренней части остатки построек не фиксируются.

Цахилдагын-худук-2 (рис. 4; 8: 3). Чойболсан сомон Дорнод аймака Монголии, в 2,9 км юго-юго-западнее городища Цахилдагын- худук-1, в 14,3 км юго-юго-восточнее вала. Валы на всем своем протяжении на снимке демонстрируют хорошую сохранность, без разрывов. Диаметр городища 232 м. Ширина вала у основания приблизительно 10 м. Во внутренней части остатки построек не фиксируются.

Дунгой-цаган-нур (рис. 4; 8: 4). Сэрггэлэн сомон Дорнод аймака Монголии, в 7,3 км к северо-востоку от соленого озера Яхийн-Нур, на южном побережье двух соленых озер Дунгой-Цаган-Нур, в зоне излияния родников. Вал в нескольких местах прорезан руслами вод, текущих от родников к озеру. Городище имеет форму круга диаметром 327 м. Ширина вала у основания приблизительно 10,5 м. Городище находится в 16,2 км южнее поворотной точки вала в районе городища Мэлхийн-булаг (поворотная точка находится в 2,6 км западнее городища), маркирующего конец западного участка Великой киданьской стены. Во внутренней части остатки построек не фиксируются.

Обращает на себя внимание, что большие круглые городища расположены в зоне центрального участка вала. Отмечается, что центральная часть вала «была наиболее удобна для нападения кавалерии противника с севера. Здесь отсутствовали такие естественные преграды, как горные хребты, располагавшиеся к северу от западного участка вала, или реки Аргунь и Гэньхэ, защищавшие восточный участок вала. Группы городищ, располагающиеся здесь, образовывали единую эшелонированную оборону важных в стратегическом отношении распадков» (Крадин и др., 2019, с. 75). Вне всякого сомнения, большие круглые городища являлись важной частью этой единой эшелонированной обороны. Их размеры и расположение наводят на мысль о крупном военном гарнизоне, располагавшемся в глубине пограничного фронтиpa.

Две группы городищ были выявлены в бассейне р. Толы, в Баяннур сомоне Булганского аймака Монголии, в болотистой пойме одной из проток р. Толы, огибающей гору Баян-Улан. Группа городищ Урто-Худук хэрэм располагается вдоль левого берега протоки, другая группа из комплексов Дэрсэн хэрэм расположена западнее и тяготеет к правому берегу протоки. Памятники Дэрсэн хэрэм I и II были открыты в 2002-2003 гг. (Очир и др., 2015, с. 86), нами были выявлены еще 4 объекта из этой группы. 


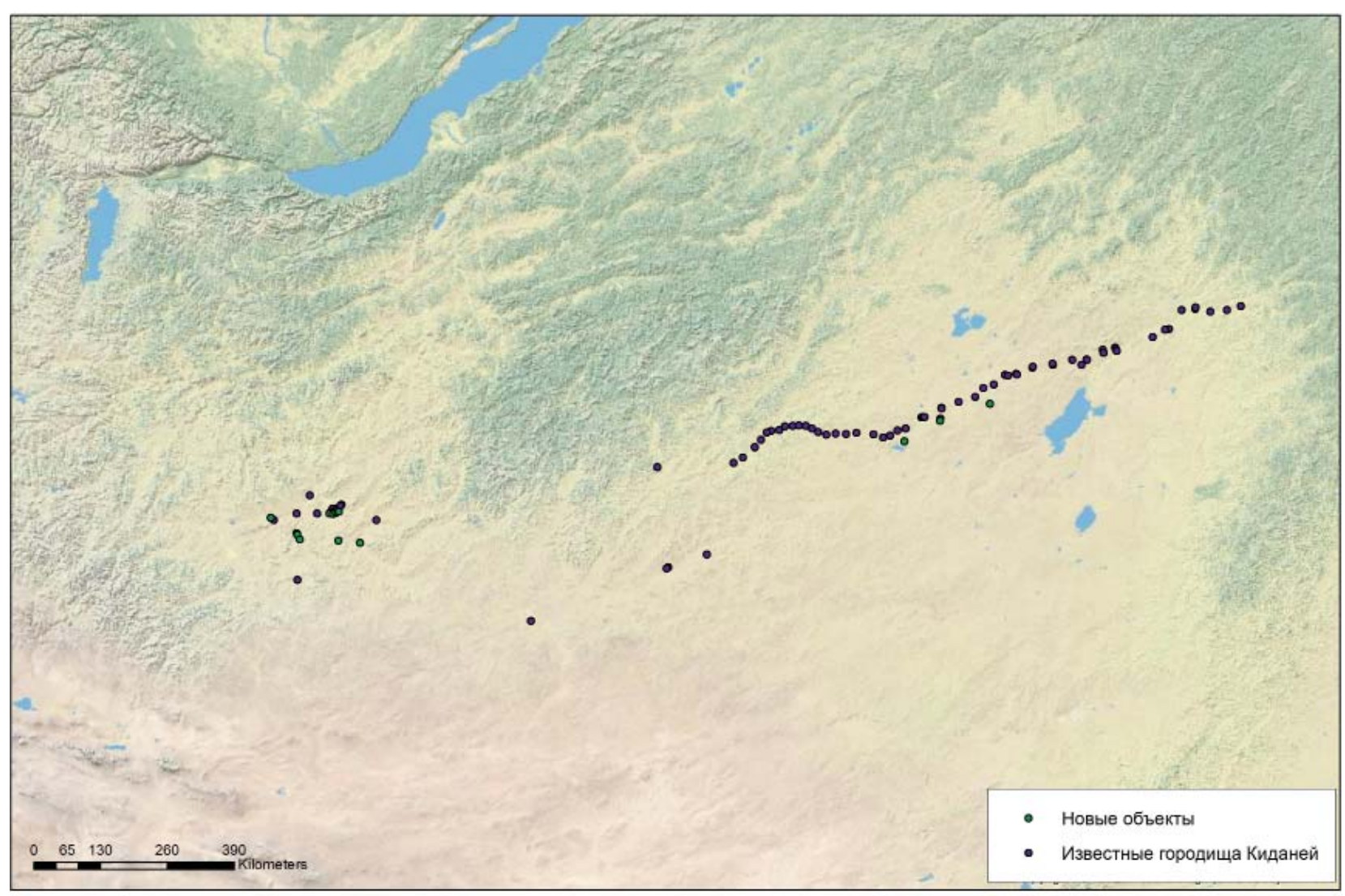

Рис. 4. Карта распространения городищ киданей в Монголии

Fig. 4. Map of distribution of the Khitan hillforts in Mongolia

Урто-Худук хэрэм I (рис. 4; 8: 5) занимает крайнее западное положение из серии этих пяти городищ, ориентировано по сторонам света, имеет прямоугольную форму, длинной осью с незначительным отклонением ориентировано с севра на юг, валы имеют размеры $175 \times 126$ м, ширина в основании около 10 м. Во внутренней части остатки построек не фиксируются.

Урто-Худук хэрэм II (рис. 4; 8: 6) находится в 3,9 км северо-восточнее первого городища, ориентировано по сторонам света, имеет прямоугольную форму, длинной осью с незначительным отклонением ориентировано с севера на юг, юго-западная часть городища разрушена, на снимках виден северный вал и часть восточного. Длина северной стены 116 м, восточной - 124 м, ширина вала в основании 6-8 м. Во внутренней части остатки построек не фиксируются.

Урто-Худук хэрэм III (рис. 4; 8: 7) расположено в 620 м севернее второго городища, ориентировано по сторонам света, имеет прямоугольную форму, длинной осью с незначительным отклонением ориентировано с севера на юг, размеры 136×126 м, валы невысокие, ширина более 10 м. Во внутренней части остатки построек не фиксируются.
Урто-Худук хэрэм IV (рис. 4; 8: 8) находится в 3,4 км северо-восточнее третьего городища на участке надпойменной террасы, прямоугольной формы, длинной осью ориентировано с северо-востока на юго-запад, размеры $86 \times 96$ м, валы невысокие, ширина около 4-5 м. Во внутренней части остатки построек не фиксируются.

Урто-Худук хэрэм V (рис. 4; 9: 1) находится в 270 м северо-восточнее четвертого городища на участке надпойменной террасы, прямоугольной формы, длинной осью ориентировано с северо-запада на юго-восток, размеры $86 \times 77$ м, валы невысокие, ширина около 10 м. Во внутренней части остатки построек не фиксируются.

Дэрсэн хэрэм III (рис. 4; 9: 2) находится в 1,3 км юго-восточнее четвертого городища в заболоченном русле протоки р. Толы, квадратной формы, длинной осью ориентировано с северо-запада на юго-восток, длина северной и южной стен 75 м, западного и восточного 88 м, ширина валов около 8 м. Во внутренней части остатки построек не фиксируются.

Дэрсэн хэрэм IV (рис. 4; 9: 3) расположено в 100 м юго-западнее третьего городища, квадратной формы, со стенами по 105 м, ширина валов более 10 м. Во внутренней части остатки построек не фиксируются. 




Рис. 5. Карта распространения городов Монгольской империи

Fig. 5. Map of the distribution of the cities of the Mongol Empire

Дэрсэн хэрэм V (рис. 4; 9: 4) находится в 899 м юго-западнее городища Дэрсэн хэрэм I, прямоугольной формы, длинной осью вытянуто с юго-запада на северо-восток, в центральной части северного и южного валов фиксируются ворота. Длина северной и южной стен 302 м, западной и восточной 89 м, ширина валов около 10 м. Во внутренней части остатки построек не фиксируются. Городище Дэрсэн хэрэм V идентично городищу Дэрсэн хэрэм II (Очир и др., 2015, с. 86-87, рис. 4).

Дэрсэн хэрэм VI (рис. 4; 9: 5) находится в 689 м южнее городища Дэрсэн хэрэм V, прямоугольной формы, длинной осью вытянуто с запада на восток, северный и часть восточного вала смыты рекой. Видимая длина западного вала 170 м, восточного 90 м, южного 270 м, ширина валов в основании более 10 м. Внутреннее пространство городища, очевидно, было разделено на отдельные кварталы, в западной части сохранились внутренние валы, один проходит параллельно внешней западной стене, на расстоянии около 40 м, от него проведен еще один, он проходит параллельно южной стене в западном направлении на расстоянии около 30 м от южного вала. На остальной площади остатки конструкций не фиксируются.
Хэрмэн дэрс II (рис. 4; 9: 6) находится в 4,9 км северо-западнее городища Хэрмэн дэрс I, на правом берегу р. Асгат Гол, ориентировано по сторонам света, трапециевидной формы, длинной осью вытянуто с запада на восток. Длина северного вала 410 м, восточного - 348 м, южного - 408 м, западного - 368 м, ширина валов около 8 м. Во внутренней части городища фиксируется земляная насыпь.

Следующее городище возможно было как-то связано с группой из трех городищ Цаган-Узурийн хэрэм (Очир и др., 2015, с. 86), оно расположено в той же долине, в 6 км южнее их.

Цаган Узурийн хэрэм IV (рис. 4; 9: 7). Рашант сомон Булганского аймака Монголии, в 6,8 км юго-восточнее городища Цаган Узурийн хэрэм III, на правом берегу р. Бадын Гол (по Очир и др., 2015, - р. Саван) и уже относится к Рашант сомону. Углами ориентировано по сторонам света, квадратной формы, северо-западный вал виден плохо. Длина стен достигает 119 м, ширина валов в основании около 7 м. Во внутренней части городища объекты не фиксируются.

Сант Улын балгас (рис. 4; 9: 8). Ондорширээт сомон Тув аймака Монголии, на правом берегу р. Бадын Гол (по Очир и др., 2015, - p. Саван). Углами городище ориенти- 

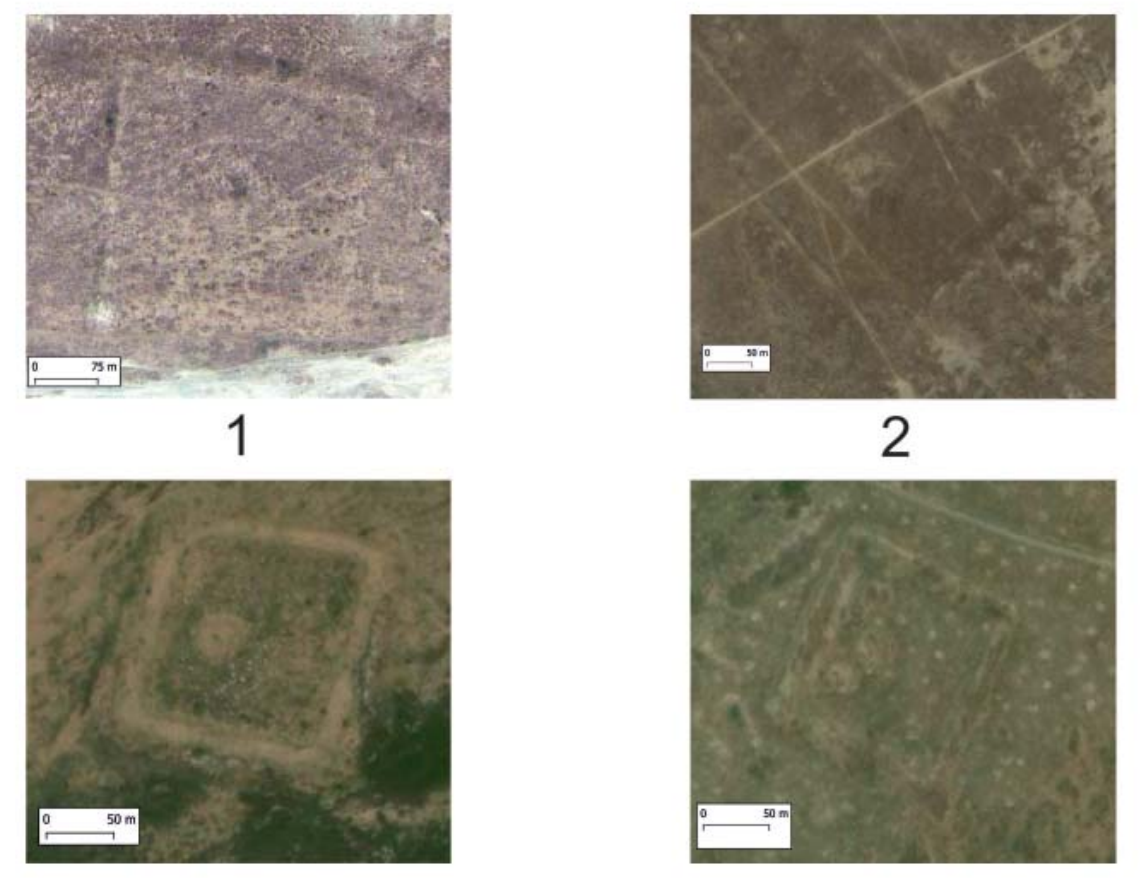

3

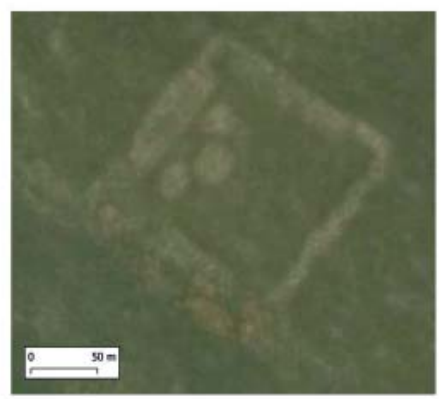

4



5

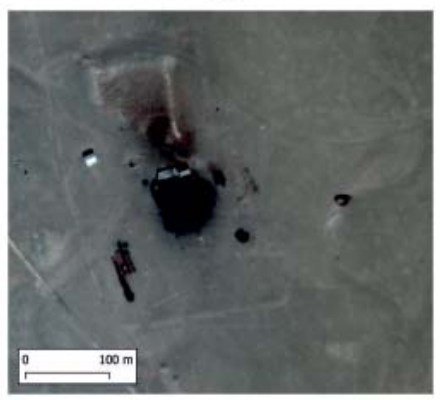

7

6

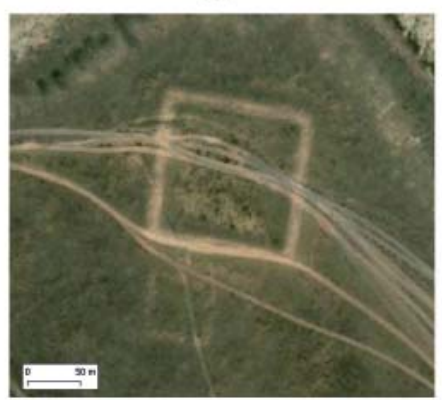

8

Рис. 6. Спутниковые снимки новых городищ хунну: 1 - Бага-Бэрх-Уула балгас; 2 - Омог-Ула-хэрэм; 3 - Цохетын Булаг I; 4 - Цохетын Булаг II; 5 - Арвай-Хэр балгас I; 6 - Арвай-Хэр балгас II; 7 - Арвай-Хэр балгас III; 8 - Баян-Гол балгас

Fig. 6. Satellite images of new Xiongnu hillforts: 1 - Baga-Berkh-Uula balgas; 2 - Omog-Ula-herem; 3 - Tsohetyn Bulag I; 4 - Tsohetyn Bulag II; 5 - Arvai-Kher balgas I; 6 - Arvai-Kher balgas II; 7 - Arvai-Kher balgas III; 8 - Bayan-Gol balgas

ровано по сторонам света, трапециевидной формы. Длина северо-восточного вала 252 м, юго-восточного - 263 м, юго-западного 260 м, северо-западного - 252 м, в середине юго-западного вала располагаются ворота П-образной формы (захаб), с внешней стороны вала прослеживается ров, ширина форти- фикационных сооружений достигает 16 м. Во внутренней части городища объекты не фиксируются.

\section{Монгольские городища}

Тахилгат-Обо балгас (рис. 5; 10: 1). Гучин ус сомон Убэрхангайского аймака Монголии, на южной оконечности возвышенности, 


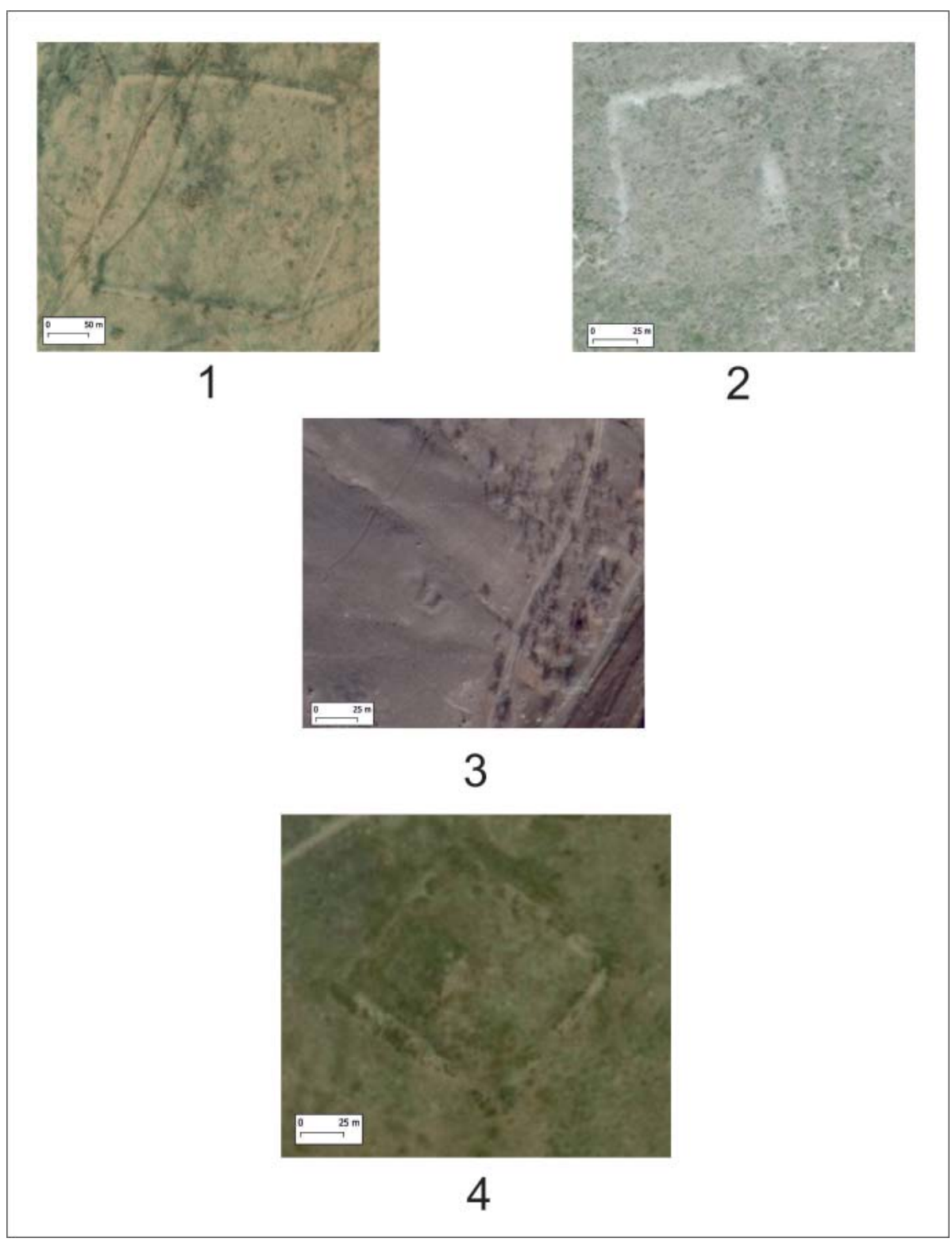

Рис. 7. Спутниковые снимки новых городищ хунну и уйгуров: 1 - Гун-Обо балгас; 2 - Китайская пограничная крепость Бордзонгийн-Булаг; 3 - городище вблизи с. Колобки; 4 - Хараат 8

Fig. 7. Satellite images of new hillforts of the Xiongnu and Uighurs: 1 - Gun-Obo balgas; 2 - Bordzongiin-Bulag; 3 - hillfort near the village Koloboki; 4 - Kharaat 8

в зоне излияния родников, ориентировано по сторонам света, квадратной формы. Городище укреплено двойной линией оплывших валов, внешний вал имеет размеры 29×29 м, внутренний - $17 \times 17$ м, ширина внешнего вала около 7 м, внутреннего - около 4 м. В 88 м восточнее прослеживаются остатки еще одной конструкции с валами прямоугольной формы, разделенной внутренними валами на три части. Эта конструкция ориентирована длинной осью с запада на восток, с северной стороны длина ее достигает 60 м, с восточной - 30 м, западная сторона не читается.

Три больших круглых городища, расположенных в ряд с запада на восток, были зафиксированы с южной стороны централь- ной части хребта Гурван Сайхан в Баяндалай сомоне аймака Умнеговь.

Гурван Сайхан 1 (рис. 5; 10: 2) занимает крайнее западное положение и самое крупное в группе, имеет подовальную форму, максимальный диаметр с севера на юг достигает 230 м, в северной части прослеживаются ворота (захаб).

Гурван Сайхан 2 (рис. 5; 10: 2) расположено в центре, в 250 м западнее первого городища, имеет подовальную форму, максимальный диаметр с севера на юг достигает 220 м, в северной части прослеживаются ворота (захаб).

Гурван Сайхан 3 (рис. 5; 10: 2), расположено городище в 520 м западнее второго 


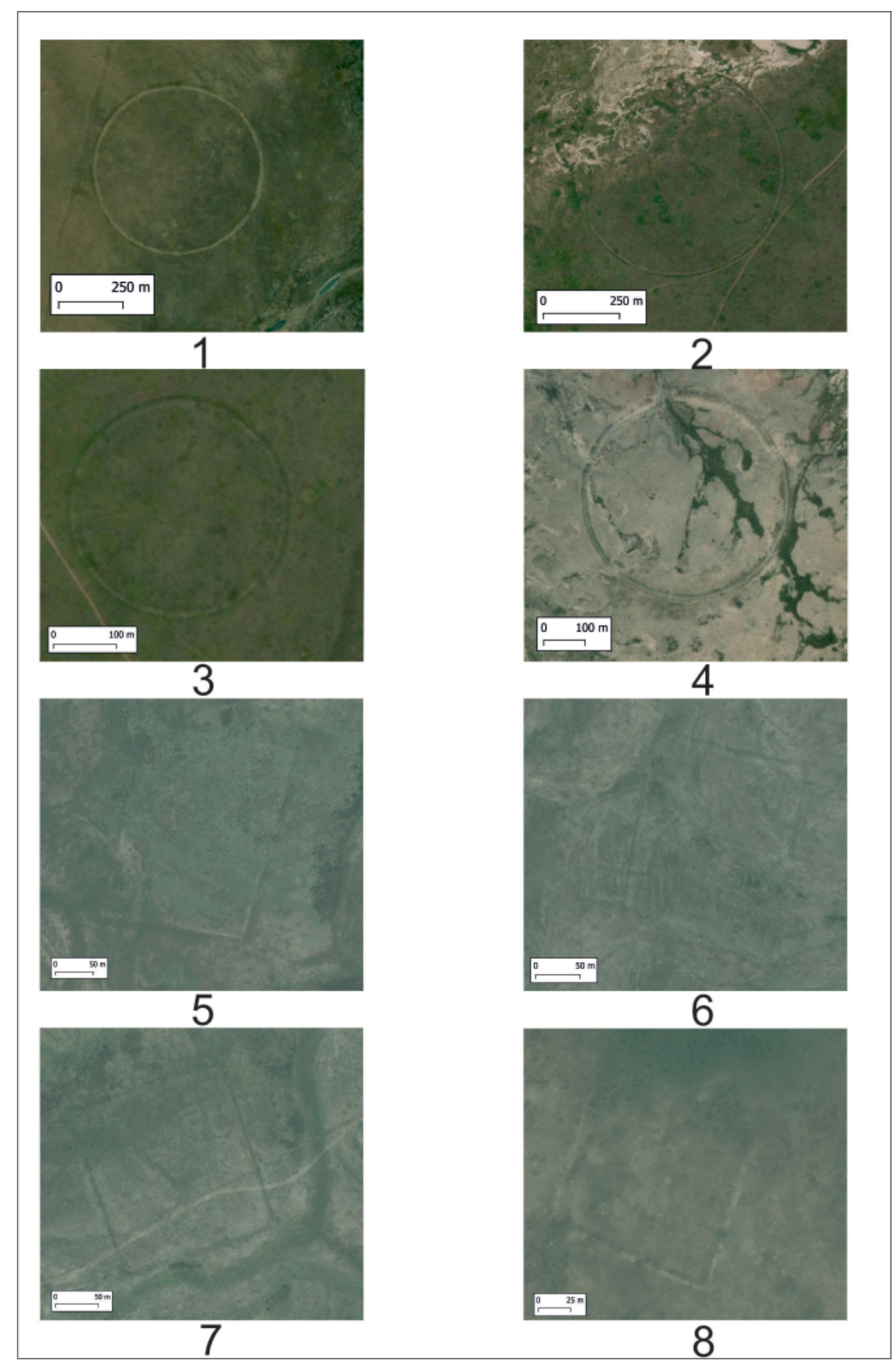

Рис. 8. Спутниковые снимки новых городищ киданей: 1 - Цаган-нур; 2 - Цахилдагын-худук-1; 3 - Цахилдагынхудук-2; 4 - Дунгой-цаган-нур; 5 - Урто-Худук хэрэм I; 6 - Урто-Худук хэрэм II; 7 - Урто-Худук хэрэм III; 8 - Урто-Худук хэрэм IV

Fig. 8. Satellite images of new hillforts of the Khitan: 1 - Tsagan-Nur; 2 - Tsakhildagyn-huduk-1; 3 - Tsakhildagynhuduk-2; 4 - Dungoi-tsagan-nur; 5 - Urto-Khuduk herem I; 6 - Urto-Khuduk herem II; 7 - Urto-Khuduk herem III; 8 - Urto-Khuduk harem IV

городища, имеет подовальную форму, максимальный диаметр с севера на юг около 140 м, в северной части прослеживаются ворота (захаб).

Дабатуйское городище (рис. 5; 10: 5). Расположено в 1,4 км южнее с. Дабатуй Бичурского района Республики Бурятия, на левом берегу речки Дабатуйки. Городище приурочено к пологому склону юго-восточной экспозиции, к северной мысовидной оконечности горного кряжа. Городище прямоугольной формы, вытянуто с северо-запада на юговосток, ориентировочные размеры $100 \times 60 \mathrm{~m}$, валы невысокие, северный вал сильно оплывший. Во внутренней части остатки конструкций не фиксируются. 


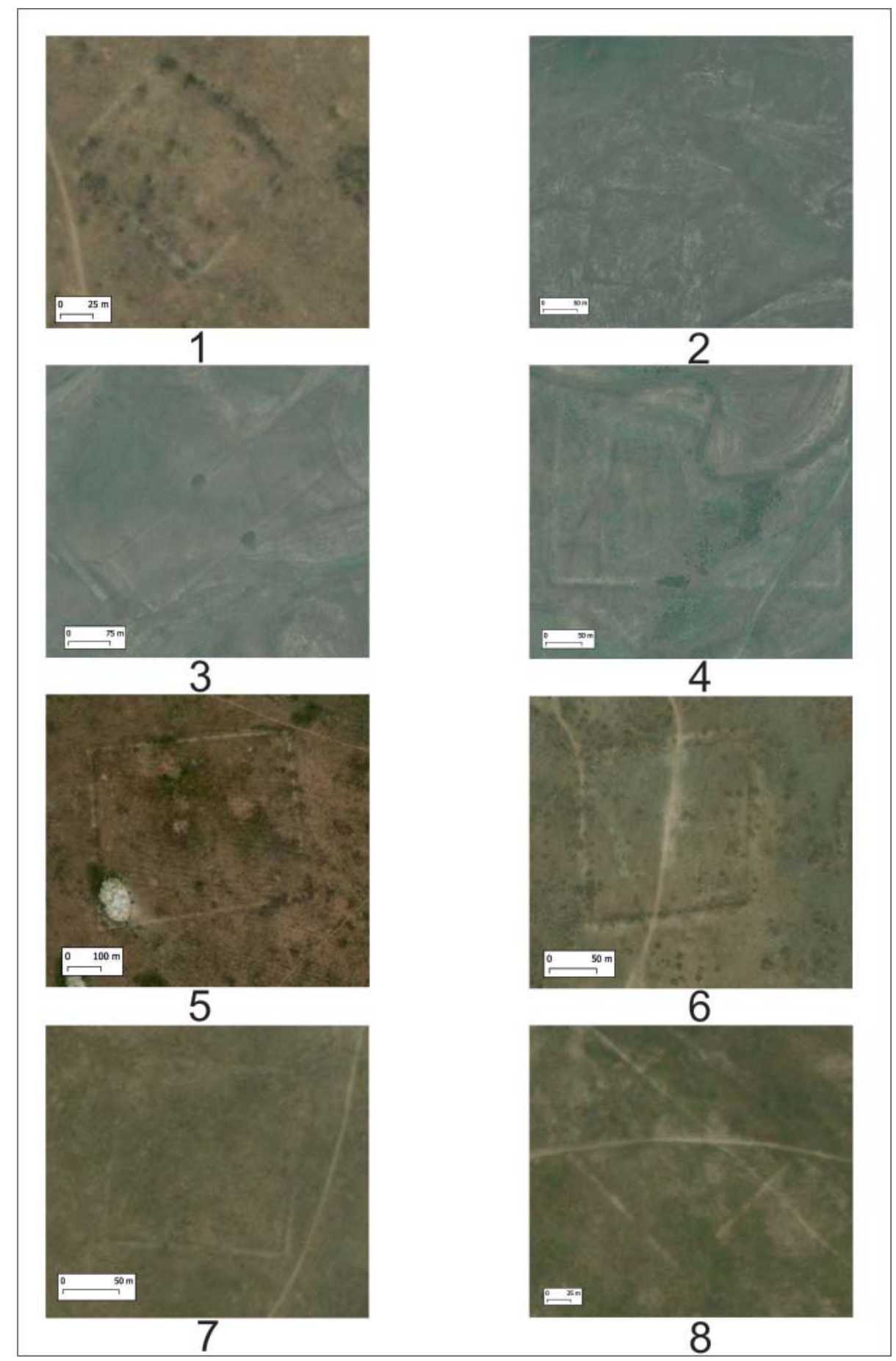

Рис. 9. Спутниковые снимки новых городищ киданей: 1 - Урто-Худук хэрэм V; 2 - Дэрсэн хэрэм III; 3 - Дэрсэн хэрэм IV; 4 - Дэрсэн хэрэм V; 5 - Дэрсэн хэрэм VI; 6 - Хэрмэн дэрс II; 7 - Цаган Узурийн хэрэм IV; 8 - Сант Улын балгас

Fig. 9. Satellite images of new hillforts of he Khitan: 1 - Urto-Khuduk herem V; 2 - Dersen herem III;

3 - Dersen herem IV; 4 - Dersen herem V; 5 - Dersen herem VI; 6 - Herman Ders II; 7 - Tsagan Uzuriyn herem IV; 8 - Sant Ulyn balgas

Таким образом, в ходе мониторинга спутниковых снимков из свободных источников - Google, Bing и Esri - с помощью картографической программы SAS Planet нами были выявлены новые объекты с элементами фортификации. Подобные памятники широко распространены на территории Монголии, а также на сопредельных территориях. Новые городища были предварительно датированы от периода владычества в Центральной Азии хуннской державы до Империи монголов. Безусловно, датировка этих памятников и полноценное описание их конструктивных особенностей возможны только при непосредственном обследовании на месте, но тем не менее очень показательно, что в результа- 


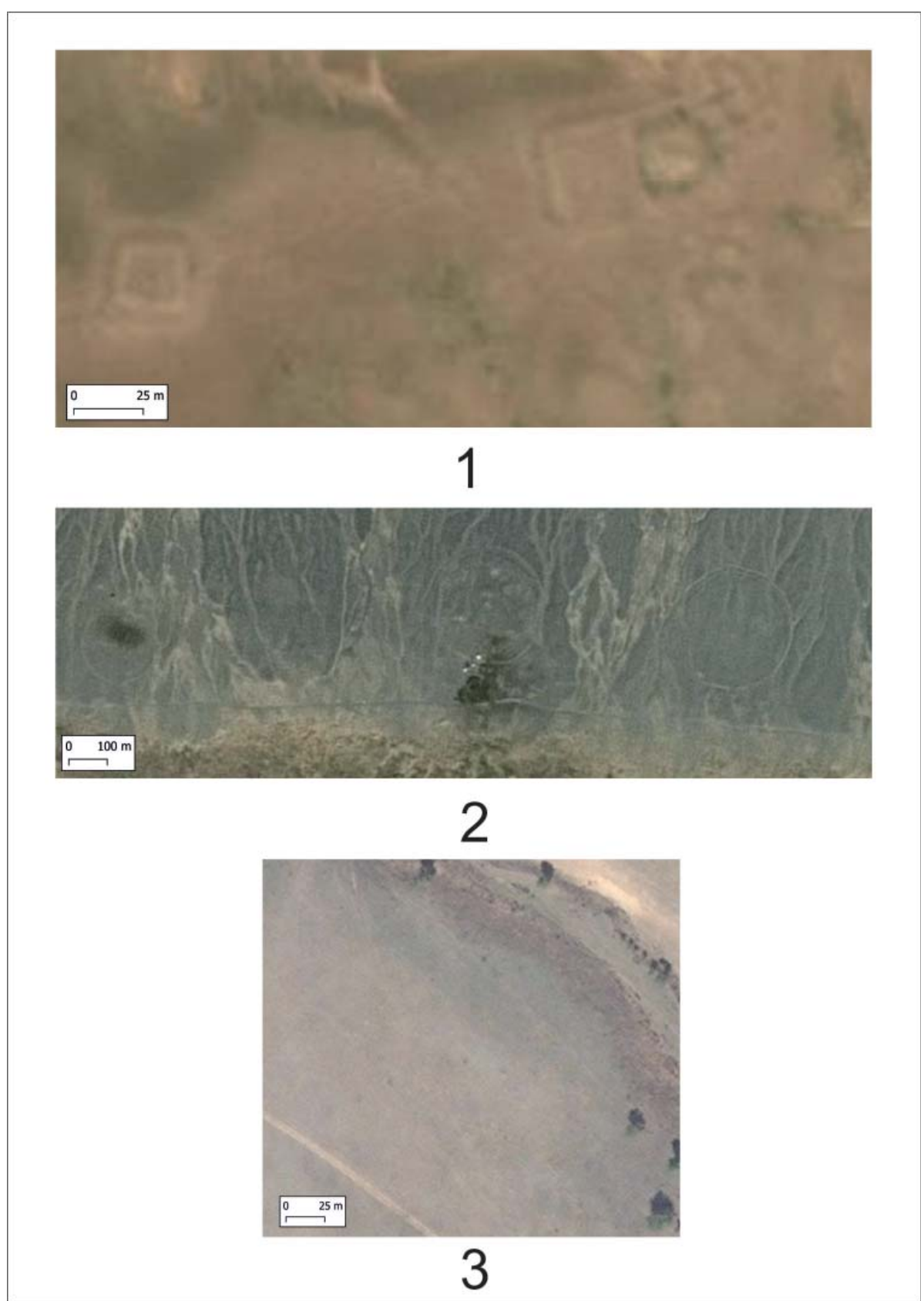

Рис. 10. Спутниковые снимки новых городищ монгольского времени: 1 - Тахилгат-Обо балгас;

2 - Гурван Сайхан 1, Гурван Сайхан 2, Гурван Сайхан 3; 3 - Дабатуйское городище

Fig. 10. Satellite images of new hillforts of Mongolian time: 1 - Takhilgat-Obo balgas;

2 - Gurvan Sayhan 1, Gurvan Sayhan 2, Gurvan Sayhan 3; 3 - Dabatui hillfort

те дистанционного обследования (дешифри- нейшее понимание и решение актуальных рования спутниковых снимков) был выявлен проблем процесса урбанизации в кочевой ряд новых объектов, исследование которых среде Центральной Азии.

может внести значительный вклад в даль-

\section{ЛИТЕРАТУРА}

Анхбаяр Б. Хуннское поселение в Заан Хошуу // Актуальные вопросы археологии этнологии Центральной Азии: Материалы II Международной научной конференции (г. Улан-Удэ, 4-6 декабря 2017 г.). / Отв. ред. Б.В. Базаров, Н.Н. Крадин. Улан-Удэ: Изд-во БНЦ СО РАН, 2017. С. 90-100.

Давыдова А.В. Иволгинский археологический комплекс. Т. І. Иволгинское городище. СПб.: Фонд «АзиатИКА», 1995. $286 \mathrm{c}$.

Данилов С.В. Города в кочевых обществах Центральной Азии. Улан-Удэ: БНЦ СО РАН, 2004. 202 с.

Данилов С.В., Именохоев Н.В., Нанзатов Б.З., Симухин А.И., Очир А., Эрдэнэболд Л. Города эпохи хунну на востоке Монголии // Известия Иркутского Государственного университета. Серия: Геоархеология. Этнология. Антропология. 2016. №17. С. 74-93. 
Древнемонгольские города / Отв. ред. С.В. Киселев. М.: Наука, 1965. 372 с.

Ивлиев А.Л. Городища киданей // Материалы по древней и средневековой археологии юга Дальнего Востока СССР и смежных территорий / Отв. ред. В.Д. Леньков. Владивосток: ДВНЦ АН СССР, 1983. C. 120-133.

Идэрхангай Т. Хүннүгийн хааны зуны ордон Лунчэн буюу луут хот (Лунчэн - город дракона - летняя резиденция шаньюев Хунну). Доклад представлен на International Conference "The Eurasian Ancient Network: Xiongnu and the Han”, г. Пусан, Южная Корея, 2021 30.04.2021.

Киселев С.В. Город монгольского Исункэ на р. Хирхира в Забайкалье // СА. 1961. №4. С. 103-127.

Крадин Н.Н. Восточная Европа и моногольская глобализация // Stratum plus. 2016. №5. С. 17-25.

Крадин Н.Н. Города в средневековых кочевых империях Монгольских степей // Средние века. 2011. T. 72. № 1-2. С. 330-351.

Крадин Н.Н., Ивлиев А.Л. Результаты археологических исследований киданьских городов в Монголии // Вестник ДВО РАН. 2011. №1. С. 111-121.

Крадин Н.Н., Ивлиев А.Л., Васютин С.А. Киданьские города конца X - начала XI в. в центральной Монголии и социальные процессы на периферии империи Ляо // Вестник Томского государственного университета. История. 2013. № 2 (22). С. 53-57.

Крадин Н.Н., Ивлиев А.Л., Васютин С.А., Харинский А.В., Очир А., Ковычев Е.В., Эрдэнэболд Л. Раскопки городища Тэрэлжийн-Дурвулжин и некоторые итоги изучения хуннской урбанизации // Актуальные вопросы археологии этнологии Центральной Азии: Материалы II Международной научной конференции (г. Улан-Удэ, 4-6 декабря 2017 г.). / Отв. ред. Б.В. Базаров, Н.Н. Крадин. Улан-Удэ: Изд-во БНЦ СО РАН, 2017. С. 90-100.

Крадин Н.Н., Ивлиев А.Л. История киданьской империи Ляо (907-1125). М.: Наука, 2014. 351 с.

Крадин Н.Н., Бакшеева С.Е., Ковычев Е.В., Харинский А.В., Прокопеи С.Д. Археология империи Чингис-хана в Монголии и Забайкалье // Stratum plus. Археология и культурная антропология. 2016. № 6. C. 17-43.

Крадин Н.Н., Харинский А.В., Прокопеи С.Д., Ивлиев А.Л., Ковычев Е.В., Эрдэнэболд Л. Великая киданьская стена: северо-восточный вал Чингис-хана. М.: Наука, 2019. 168 с.

Коновалов П.Б. К исследованию древнего поселения Баян Булаг в Южно-Гобийском аймаке Монголии // Вестник БНЦ СО РАН. 2018. № 1 (29). С. 9-16.

Очир А., Одбаатар Ц., Эрдэнболд Л., Анхбаяр Б. Монгол улсын нутаг дахь уйгурчуудын археологийн дурсгал (Археологические памятники уйгуров в Монголии). Улаанбаатар, 2019. 307 с.

Очир А., Эрдэнболд Л., Энхтур А. Исследования киданьских городищ и других сооружений в Монголии // Междисциплинарные исследования в археологии. 2015. Вып. 2. Городища и поселения. С. 84-95.

Пэрлээ X. Монгол Ард Улсын эрт, дундад үеийн хот суурины товчоон // Бүтээлийн чуулган. I боть. 1961 (2012) (Краткий очерк древнихи средневековых городов и поселений на территории Монголии). 1961.

Эрэгзэн $Г$. Новые гипотезы о назначении и конструктивных особенностях хуннского городища Гуадов // Актуальные вопросы археологии этнологии Центральной Азии: Материалы II Международной научной конференции (г. Улан-Удэ, 4-6 декабря 2017 г.). / Отв. ред. Б.В. Базаров, Н.Н. Крадин. Улан-Удэ: Изд-во БНЦ СО РАН, 2017. С. 245-255.

Ancient settlement of Mongolia / Archaeological relics of Mongolia catalogue series. Vol. 10. Ulaanbaatar, 2020. 284 p.

Bemmann J., Reichert S. Karakorum, the first capital of the Mongol world empire: an imperial city in a non-urban society // Asian Archaeology. 2020. №4 (1). P. https://doi.org/10.1007/s41826-020-00039-x

Chen Gaohua. The Capital of the Yuan Dynasty. Honolulu: Hawaii University Press. 2015.

Evans D. Airborne laser scanning as a method for exploring long-term socio-ecological dynamics in Cambodia // Journal of Archaeological Science. 2016. Vol. 74. P. 164-175. https://doi.org/10.1016/j.jas.2016.05.009.

Hayashi T. Agriculture and Settlements in the Hsiung-nu // Bulletin of the Ancient Orient Museum. 1984. Vol. 6. P. 51-92.

Hüttel H.-G., Erdenebat U. Karabalgasun und Karakorum: zwei spätnomadische Stadtsiedlungen im Orchon-Tal. Ulaanbaatar: Erdem. 2009.

Inomata, T., Triadan, D., Vázquez López, V.A. et al. Monumental architecture at Aguada Fénix and the rise of Maya civilization // Nature. 2020. Vol. 582. P. 530-533. https://doi.org/10.1038/s41586-020-2343-4.

Kradin N. N., Ivliev A. L., Ochir A., Erdenebold L., Vasiutin S. A., Sarantseva S. E., Kovychev E. V. Khermen Denz Town in Mongolia // The Silk Road. 2015. 13, 95-103. 
Marcello A. Canuto, Francisco Estrada-Belli, Thomas G. Garrison, Stephen D. Houston, Mary Jane Acuña, Milan Kováč, Damien Marken, Philippe Nondédéo, Luke Auld-Thomas, Cyril Castanet, David Chatelain, Carlos R. Chiriboga, Tomáš Drápela, Tibor Lieskovský, Alexandre Tokovinine, Antolín Velasquez, Juan C. Fernández-Díaz, Ramesh Shrestha. Ancient lowland Maya complexity as revealed by airborne laser scanning of northern Guatemala // Science. 2018. Vol. 361, Issue 6409. DOI: 10.1126/science.aau0137.

Ramseyer D., Pousaz N., Törbat T. The Xiongnu Settlement of Boroo Gol, Selenge Aimag, Mongolia // Current Archaeological Research in Mongolia. Papers from the First International Conference on «Archaeological Resesarch in Mongolia» held in Ulaanbaatar, August $19^{\text {th }}-23^{\text {rd }} 2007$. Bonn: Rheinische FriedrichWilhelms-Universitat Bonn, 2009. P. 231-240.

Shiraishi N. Avraga Site: The "Great Ordu" Of Genghis Khan // Beyond the Legacy of Genghis Khan. Leiden; Boston: Brill, 2006. P. 94-110.

The Xiongnu / ed. by G. Eregzen, Yang Si-Eun. 2017.

\section{Информация об авторах:}

Миягашев Денис Алексеевич, кандидат исторических наук, научный сотрудник, Институт монголоведения, буддологии и тибетологии СО РАН (г. Улан-Удэ, Россия); silker10@yandex.ru

Базаров Биликто Александрович, научный сотрудник, Институт монголоведения, буддологии и тибетологии СО РАН (г. Улан-Удэ, Россия); biliktobazarov@yandex.ru

Дикий Ярослав Витальевич, кандидат исторических наук, младший научный сотрудник, Институт монголоведения, буддологии и тибетологии СО РАН (г. Улан-Удэ, Россия); yaroslavdikii@gmail.com

\section{REFERENCES}

Ankhbaiar, B. 2017. In Bazarov, B.V., Kradin, N.N. (eds.). Aktual'nye voprosy arkheologii $i$ etnologii Tsentral'noi Azii (Topical Issues of Archaeology and Ethnology of Inner Asia). Ulan-Ude: Buryatia Scientific Center of the Siberian Branch of the Russian Academy of Sciences, 90-100 (in Russian).

Davydova, A. V. 1995. Ivolginskiy arkheologicheskiy kompleks. T. I. Ivolginskoe gorodishhe (Ivolginsk archaeological complex. Vol. 1. Ivolginsk fortified settlement). Saint Petersburg: "AziatIKA" Publ. (in Russian).

Danilov, S. V. 2004. Goroda v kochevykh obshhestvakh Tsentral'noy Azii (Towns in the Nomadic Societies of Central Asia). Ulan-Ude: Buryatia Scientific Center, Siberian Branch of the Russian Academy of Sciences (in Russian).

Danilov, S. V., Imenokhoev, N. V., Nanzatov, B. Z., Simukhin, A. I., Ochir, A., Erdenebold L. 2016. In Izvestiia Irkutskogo gosudarstvennogo universiteta (Proceedings of Irkutsk State University). Series: «Geoarkheologiia. Etnologiia. Antropologiia (Geoarchaeology. Ethnology. Anthropology) (17). 74-93 (in Russian).

Kiselev, S. V. (ed.). 1965. Drevnemongol'skie goroda (Early Mongol Towns). Moscow: "Nauka" Publ. (in Russian).

Ivliev, A. L. 1983. In Len'kov, V. D. (ed.). Materialy po drevnei i srednevekovoi arkheologii iuga Dal'nego Vostoka SSSR i smezhnykh territorii (Materials on Ancient and Medieval Archaeology of the Southern Part of the USSR Far East and Adjacent Territories). Vladivostok: Far Eastern Scientific Center, Academy of Sciences of the USSR, 120-133 (in Russian).

Iderkhangai, T. 2021. In International Conference "The Eurasian Ancient Network: Xiongnu and the Han" (in Russian, Mongolian).

Kradin, N. N. 2016. In Stratum plus. Archaeology and Cultural Anthropology (5), 17-25 (in Russian).

Kiselev, S. V. 1961. In Sovetskaia Arkheologiia (Soviet Archaeology) (4), 103-127 (in Russian).

Kradin, N. N. 2011. In Srednie veka (Middle Ages) 72 (1-2). 330-351 (in Russian).

Kradin, N. N., Ivliev, A. L. 2011. In Vestnik Dal'nevostochnogo Otdeleniya RAN (Vestnik of Far Eastern Branch of Russian Academy of Sciences) 1, 111-121 (In Russian).

Kradin, N. N., Baksheeva, S. E., Kovychev, E. V., Prokopets, S. D., Kharinskii, A. V. 2016. In Stratum plus. Archaeology and Cultural Anthropology (6), 17-43 (in Russian).

Kradin, N. N., Ivliev, A. L., Vasiutin, S. A. 2013. In Vestnik Tomskogo Gosudarstvennogo universiteta. Istoriia (Bulletin of the Tomsk State University: History) 22 (2), 53-57 (in Russian).

Kradin, N. N., Ivliev, A. L., Vasiutin, S. A., Kharinskii, A. V., Ochir, A., Kovychev, E. V., Erdenebold, L. 2017. In Bazarov, B. V., Kradin, N. N. (eds.). Aktual'nye voprosy arkheologii i etnologii Tsentral'noi Azii (Topical Issues of Archaeology and Ethnology of Inner Asia). Ulan-Ude: Buryatia Scientific Center of the Siberian Branch of the Russian Academy of Sciences, 163-175 (in Russian). 
Kradin, N. N., Ivliev, A. L. 2014. Istoriya kidan'skoy imperii Lyao (907-1125) (History of the Khitan Empire of Liao (907-1125). Moscow: "Nauka" Publ. (in Russian).

Kradin N.N., Baksheyeva S.Ye., Kovychev Ye.V., Kharinskiy A.V., Prokopets, S. D. 2016. In Stratum plus. Arkheologiia i kul'turnaia antropologiia (Stratum plus. Archeology and Cultural Anthropology) (6) 17-43 (in Russian).

Kradin N.N., Kharinskiy A.V., Prokopets S.D., Ivliyev A.L., Kovychev Ye.V., Erdenebold L. 2019. Velikaya kidan'skaya stena: severo-vostochnyy val Chingis-khana. Moskva (The Great Khitan Wall: the North-Eastern Rampart of Chinggis Khan). Moscow: "Nauka" Publ. (in Russian).

Konovalov, P. B. 2018. In Vestnik BNTS SO RAN (Bulletin of the Buryat Scientific Center of the Siberian Branch of the Russian Academy of Sciences) 29 (1). 9-16 (in Russian).

Ochir, A., Odbaatar, Ts., Erdenbold, L., Ankhbayar, B. 2019. Mongol ulsyn nutag dakh' uygurchuudyn arkheologiyn dursgal (Archaeological sites of the Uyghurs in Mongolia). Ulaanbaatar. (in Mongolian).

Ochir, A., Erdenbold, L., Enkhtur, A. 2015. Mezhdistsiplinarnye issledovaniia v arkheologii (Interdisciplinary Investigation in Archaeology) 2. 84-95 (in Russian).

Perlee, Kh. 1961. (2012). Mongol ard ulsyn ert, dun -dan uuiyn khot suuriny tovchoon (Essay of the Ancient and Mediaeval Towns and Settlements in Mongolian Territory). Ulaanbaatar (in Mongolian).

Eregzen, G. 2017. In Bazarov, B. V., Kradin, N. N. (eds.). Aktual'nye voprosy arkheologii $i$ etnologii Tsentral'noi Azii (Topical Issues of Archaeology and Ethnology of Inner Asia). Ulan-Ude: Buryatia Scientific Center of the Siberian Branch of the Russian Academy of Sciences, 245-255 (in Russian).

Ancient settlement of Mongolia / Archaeological relics of Mongolia catalogue series. Vol. 10. Ulaanbaatar, 2020. $284 \mathrm{p}$.

Bemmann, J., Reichert, S. 2020. In Asian Archaeology 4(1). https://doi.org/10.1007/s41826-020-00039-x

Chen Gaohua. 2015. The Capital of the Yuan Dynasty. Honolulu:Hawaii University Press.

Evans, D. 2016. In Journal of Archaeological Science (74). 164-175. https://doi.org/10.1016/j. jas.2016.05.009.

Hayashi, T. 1984. In Bulletin of the Ancient Orient Museum. 6. 51-92 (in English).

Hüttel, H.-G., Erdenebat, U. 2009. Karabalgasun und Karakorum: zwei spätnomadische Stadtsiedlungen im Orchon-Tal. Ulaanbaatar: Erdem.

Inomata, T., Triadan, D., Vázquez López, V.A. et al. 2020. In Nature (582). 530-533. https://doi. org/10.1038/s41586-020-2343-4.

Kradin, N. N., Ivliev, A. L., Ochir, A., Erdenebold, L., Vasiutin, S. A., Sarantseva, S. E., Kovychev, E. V. 2015. In The Silk Road (13) 95-103 (in English).

Marcello A. Canuto, Francisco Estrada-Belli, Thomas G. Garrison, Stephen D. Houston, Mary Jane Acuña, Milan Kováć, Damien Marken, Philippe Nondédéo, Luke Auld-Thomas, Cyril Castanet, David Chatelain, Carlos R. Chiriboga, Tomáš Drápela, Tibor Lieskovský, Alexandre Tokovinine, Antolín Velasquez, Juan C. Fernández-Díaz, Ramesh Shrestha. 2018. In Science 6409 (361). DOI: 10.1126/science.aau0137 (in English).

Ramseyer, D., Pousaz, N., Törbat, T. 2009. In Current Archaeological Research in Mongolia. Papers from the First International Conference on «Archaeological Resesarch in Mongolia» held in Ulaanbaatar, August $19^{\text {th }}-23^{\text {rd }}$ 2007. Bonn: Rheinische Friedrich-Wilhelms-Universitat Bonn. 231-240.

Shiraishi, N. 2006. In Beyond the Legacy of Genghis Khan. Leiden; Boston: Brill. 94-110 (in English).

Eregzen, G. (ed.). 2017. The Xiongnu. Yang Si-Eun.

\section{About the Authors:}

Miyagaschev Denis A. Candidate of Historical Sciences. Institute for Mongolian, Buddhist and Tibetan Studies of Siberian Branch of Russian Academy of Sciences, Sakhyanovoi Str., 6, Ulan-Ude, 670047, Russian Federation; silker10@yandex.ru

Bazarov Bilikto A. Institute for Mongolian, Buddhist and Tibetan Studies of Siberian Branch of Russian Academy of Sciences, Sakhyanovoi Str., 6, Ulan-Ude, 670047, Russian Federation; biliktobazarov@yandex. $\mathrm{ru}$

Dikiy Yaroslav V. Candidate of Historical Sciences. Institute for Mongolian, Buddhist and Tibetan Studies of Siberian Branch of Russian Academy of Sciences, Sakhyanovoi Str., 6, Ulan-Ude, 670047, Russian Federation; yaroslavdikii@gmail.com

Статья поступила в журнал 01.04.2021 г. Статья принята к публикации 01.04.2021 г. Авторы внесли равноценный вклад в работу. 